\title{
PERBEDAAN RISK AND RETURN DEPOSITO MUDHARABAH PADA BUS DI INDONESIA (PERIODE 2015-2017) ${ }^{1}$
}

\author{
Noer Cholilah \\ Departemen Ekonomi Syariah - Fakultas Ekonomi dan Bisnis - Universitas Airlangga \\ Email: lila.noerman95@gmail.com
}

Atina Shofawati

Departemen Ekonomi Syariah - Fakultas Ekonomi dan Bisnis - Universitas Airlangga Email: atinashofawati@yahoo.com

\begin{abstract}
:
This research analyzes the level of potential risks and returns received by customers from mudharabah deposit investments. In this study the authors also analyzed the relationship between the two variables whether they have differences in. The research method used is a descriptive quantitative approach. The sample in this study were 9 Islamic Commercial Banks which included: Bank Syariah Mandiri, Bank Muamalat Indonesia, BRI Syariah, BNI Syariah, BCA Syariah, Panin Syariah Bank, Syariah BTPN Bank, Maybank Syariah Indonesia, and Bank Syariah Bukopin. The results of this study indicate that there are significant differences between the risks with investment in mudharabah deposits in Islamic Commercial Banks. The support of this hypothesis is based on the average value of Risk on mudharabah deposit investment in Islamic Commercial Banks of -0.06448 , and a significance value of $0.038(p<0.05)$. This shows that the two variances are not the same and different.
\end{abstract}

Keywords: Risk, Yield, futures investment, mudharabah deposits.

\section{PENDAHULUAN}

Perbankan Syariah merupakan salah satu representasi aplikasi dari ekonomi Islam yang melarang adanya penggunaan sistem bunga dalam perekonomian khususnya perbankan, karena sistem tersebut dianggap riba yang dilarang oleh agama. Bahkan pelarangan riba ini tidak hanya oleh agama Islam namun juga oleh agamaagama lain. Hal ini dikarenakan bahwa penerapan sistem ribawi akan membawa dampak buruk seperti kerusakan moral di masyarakat.

Perkembangan perbankan syariah terhadap perbankan nasional dilndonesia sampai dengan Desember 2017 menuujukkan perkembangan yang positif di Indonesia. Terbukti dengan semakin meluasnya jaringan kantor bank-bank syariah di Indonesia. Pertumbuhan setiap bank juga sangat dipengaruhi oleh perkembangan kemampuannya dalam menghimpun dana masyarakat baik berskala kecil maupun besardengan masa pengendapan yang memadai (Muhammad, 2015:114). Dana merupakan masalah yang sangat krusial bagi bank sebagai lembaga kevangan. Apabila dana yang dihimpun oleh bank tidak mencukupi sesuai kebutuhannya, maka bank menjadi tidak berfungsi sama sekali. Kasmir (2010:45) mendefinisikan sumber dana bank sebagai usaha bank dalam

\footnotetext{
${ }^{1}$ Jurnal ini merupakan bagian dari Noer Cholilah, NIML 041311433091, yang diuji pada tanggal 31 januari 2019.
} 
menghimpun dana dari masyarakat. Perolehan dana disesuaikan pula dengan tujuan dari penggunaan dana tersebut. Maka dari itu, pemilihan sumber dana harus dilakukan secara tepat.

Salah satu cara untuk mengelola dana agar dana tersebut tidak menjadi harta diam yang kurang efektif yaitu dengan melakukan kegiatan investasi. Setiap investasi pasti akan memiliki potensi timbul terjadinya risiko. Risiko muncul karena adanya ketidakpastian. Tidak mungkin dan tidak lain jikalau suatu ketidakpastian itu dapat kita hindari.Bahwasanya di dalam ajaran Islam mengatakan bahwa tidak ada seorangpun yang mengetahui apa yang akan dihasilkan di hari esok. Sebagaimana dalam QS. Al Luqman: 34

"Sesungguhnya Allah, hanya pada sisiNya sajalah pengetahuan tentang hari Kiamat; dan Dia-lah yang menurunkan hujan, dan mengetahui apa yang ada dalam rahim.dan tiada seorangpun yang dapat mengetahui (dengan pasti) apa yang akan diusahakannya besok, dan tiada seorangpun yang dapat mengetahui di bumi mana Dia akan mati. Sesungguhnya Allah Maha mengetahui lagi Maha Mengenal". (Q.S Al Luqman: 34). Maksud dari ayat tersebut adalah bahwa manusia itu tidak dapat mengetahui dengan pasti apa yang akan diusahakannya besok atau yang akan diperolehnya, namun tetaplah mereka diwajibkan untuk berusaha. Ayat tersebut menjadi dasar pemikiran konsep risiko dalam Islam, khususnya kegiatan usaha dan investasi (QS. Al-Lukman: 34).

Dalam kegiatan usahanya bank syariah sangat membutuhkan dana masyarakat guna menjalankan kegiatan operasional, sebagaimana fungsi bank yaitu sebagai lembaga perantara antara pihak yang kelebihan dana dan pihak yang kekurangan dana. Dana pihak ketiga bank syariah didominasi oleh produk deposito mudharabah yang selalu memliliki porsi diatas $50 \%$ dari total dana pihak ketiga dan terus meningkat disetiap tahunnya. Salah satu faktor meningkatnya dana pihak ketiga dari produk deposito adalah return bagi hasilyang ditawarkan oleh bank. Disamping kinerja bank syariah yang mengesankan, sistem bagi hasil deposito mudharabah lebih stabil terhadap gejolak ekonomi makro.

Tabel 1.

Porsi Dana Pihak Ketiga Bank Syariah (dalam Miliar Rupiah)

\begin{tabular}{|c|c|c|c|}
\hline Tahun & Giro & Tabungan & Deposito \\
\hline 2012 & 11,91 & 30,13 & 57,96 \\
\hline 2013 & 10,40 & 28,25 & 61,35 \\
\hline 2014 & 12,00 & 30,55 & 57,44 \\
\hline 2015 & 10,09 & 31,17 & 58,74 \\
\hline 2016 & 8,44 & 29,47 & 62,09 \\
\hline 2017 & 9,39 & 29,11 & 61,50 \\
\hline
\end{tabular}

Sumber: Statistik Perbankan Syariah, data diolah

Hal ini menandakan besarnya kepercayaan masyarakat untuk menempatkan dananya pada bank syariah dalam bentuk investasi jangka panjang, disamping itu deposito 
mudharabah memiliki return bagi hasil yang cukup tinggi dibandingkan giro dan tabungan, sehingga banyak nasabah yang lebih memilih menggunakan produk deposito mudharabah.

Namun, merosotnya kinerja perbankan syariah dimulai pada tahun 2014 tidak lain akibat dari kondisi perekonomian global dan Indonesia yang memberikan efek negative pada industrl perbankan syariah. Kondisi perekonomian Indonesia yang melesu berakibat pada tingginya pembiayaan bermasalah yang dihadapi oleh bank syariah, pembiayaan bermasalah sangat mempengaruhi kualitas aset bank.Kondisi ini tidak hanya dialami oleh perbankan syariah saja, namun bank konvensional juga mengalami peningkatan pada besarnya kredit bermasalah akibat dari kondisi perekonomian yang kurang baik.

Pada kenyataannya bank harus tetap meberikan return kepada nasabah dengan persentase nisbah yang telah disepakati. Hal ini dilakukan oleh bank agar bank tidak kehilangan nasabah mereka.Disinilah terdapat risiko yang cukup besar bagi bank.Return bagi hasil cenderung flat, sedangkan hasil usaha atau pendapatan bank yang tidak selalu sama atau bersifat fluktuatif. Dengan demikian, bank harus menyisihkan dana dari modal atau aset mereka untuk menutupi pemberian return atau imbal hasil yang kurang (Karim, 2013).

Risiko imbal hasil atau risk return yang dihadapi bank syariah tidak bisa dipandang sebelah mata. Hal tersebut telah diatur dalam Peraturan Bank Indonesia No.13/23/PBI/2011 yang berisi bahwa bank syariah harus menambah dua penerapan manajemen risiko dimana sebelumnya terdapat delapan manajemen risiko menjadi sepuluh manajemen risiko, risiko imbal hasil (rate of return risk) dan juga risiko investasi (equity investment risk). Terjadinya risk return, akan mengurangi keuntungan yang didapat oleh bank sehingga mempengaruhi tingkat bagi hasil yang diberikan oleh bank kepada nasabah. Akibat yang akan terjadi ialah nasabah bank akan berpindah kepada lembaga keuangan lainnyya yang memiliki return bagi hsil yang lebih tinggi.

Oleh karena itu penulis akan menganalisis lebih jauh risiko bagi hasil deposito mudharabah bank syariah. Selain mengetahui bagi hasil, penulis juga ingin mengetahui seberapa besar risiko bank syariah dalam menginvestasikan dana deposito mudharabah. Banyak cara untuk menganalisis risiko, salah satunya adalah dengan menggunakan metode RAROC (Risk Adjusted Return on Capital)

Metode pengukuran RAROC digunakan untuk mengukur return/imbal hasil yang disesuaikan dengan risiko. RAROC adalah suatu Ukuran profitabilitas yang telah disesuaikan dengan besarnya risiko bahwa pengelolaan memungkinkan untuk alokasi modal, menghubungkan biaya dan menyangkut pada risiko kredit, risiko pasar, dan risiko operasional 
terhadap berbagai macam transaksi, klien dan jalur usaha. Melalui pendekatan ini maka bobot risiko dan bobot imbal hasil dapat terukur. Sehingga investor akan memperoleh peluang return atau nilai bagi hasil yang optimal dan prospektif (Prabowo, 2009).

Peneliti berusaha mengamati, apakah risiko dan imbal hasil antar Bank Umum Syariah yang ada di Indonesia memiliki perbedaan.Penelitian ini menggunakan data laporan tahunan Bank Syariah terkait yang dipublikasikan.Laporan keuangan tahunan pada perbankan menunjukkan kinerja keuangan yang telah dicapai perbankan pada suatu periode.

Diharapkan dalam penelitian ini dapat diketahui perbedaan antara tingkat risiko dengan tingkat imbal hasil investasi deposito mudharabah yang telah disesuaikan oleh risiko yang dimiliki Bank Syariah di Indonesia, sehingga para calon investor memiliki informasi yang cukup untuk bisa melakukan perhitungan terhadap investasi yang akan dilakukan.

Perbedaan penelitian ini dengan penelitian sebelumnya ialah terdapat pada metode analisinya yang menggunanakan metode RAROC (Risk Adjustment of Capital). Dalam penelitian sebelumnya menggunakan dua metode yaitu VaR dan RAROC, namun dalam penelitian ini hanya menggunakan meode RAROC karena menurut peneliti metode RAROC ini sudah mewakili dalam perhitungan risiko dan imbal hasil, artinya tidak perlu melakukan perhitungan di tiap variabel dengan metode yang berbedabeda. Selain itu kelebihan dari RAROC adalah bahwa metode ini dapat diaplikasikan ke seluruh produk-produk finansial yang diperdagangkan.Selain itu hasil perhitungan RAROC biasanya disajikan dalam bentuk jumlah uang dan bukan dalam persentase. Hal ini membuat RAROC menjadi sangat mudah dipahami untuk melakukan pengukuran dengan tidak memakan waktu yang cukup lama. Berdasarkan uraian yang telah dijelaskan, maka rumusan masalah dalam penelitian ini adalah: apakah terdapat perbedaan risiko investasi deposito mudharabah pada Bank Umum Syariah di Indonesia; apakah terdapat perbedaan imbal hasil investasi deposito mudharabah pada Bank Umum Syariah di Indonesia?

\section{LANDASAN TEORI}

\section{Bank Umum Syariah}

Bank Umum Syariah adalah bank yang dalam aktivitasnya, baik itu penghimpunan dana maupun penyaluran dananya memberikan dan menggunakan imbalan atas dasar prinsip syariah yaitu jual beli dan bagi hasil. Prinsip utama dari bank syariah bersarakan prinsip syariah yaitu hukum islam yang bersumber pada Al-Qur'an dan Hadits yang melarang melakukan riba dan melakukan investasi pada usaha-usaha yang digolongkan haram (Sudarsono, 2007:27).

\section{Fungsi Bank Umum Syariah}

Menurut Sudarsono (2008:43-44)

Bank Umum Syariah memiliki beberapa fungsi diantaranya sebagai berikut: (1) 
Sebagai Manajemen Inventasi, (2)

Sebagai Investasi, (3) Sebagai Jasa

Keuangan, (4) Sebagai Jasa Sosial

\section{Kegiatan Bank Umum Syariah}

Berdasarkan Booklet Perbankan Indonesia (2011) kegiatan bank umum syariah terdiri atas:

1. Menghimpun dana dalam bentuk simpanan giro, tabungan, atau bentuk lainnya berdasarkan akad wadi'ah atau akad lainnya yang tidak bertentangan

2. Menghimpun dana dalam bentuk investasi berupa deposito, tabungan, atau bentuk lainnya berdasarkan akad mudharabah atau akad lainnya yang tidak bertentangan

3. Menyalurkan pembiayaan berdasarkan akad qardh atau akad lainnya yang tidak bertentangan

4. Melakukan pengembalian utang berdasarkan akad hiwalah atau akad lainnya yang tidak bertentangan

\section{Investasi dalam perspektif Islam}

Menurut Huda dan Nasution (2007) menjelaskan bahwa investasi merupakan salah satu ajaran dari konsep Islam yang memenuhi proses tadrij dan trichtomy pengetahuan tersebut. Konsep investasi selain sebagai pengetahuan juga bernuansa spiritual karena menggunakan norma syariah, sekaligus merupakan hakikat dari sebuah ilmu dan amal, maka dari itu Investasi sangat dianjurkan bagi setiap umat muslim.

Sebagaimana dijelaskan dalam Q.S AlHasyr ayat 18 yang berbunyi:
Artinya: "Hai orang-orang yang beriman, bertakwalah kepada Allah dan hendaklah Setiap diri memperhatikan apa yang telah diperbuatnya untuk hari esok (akhirat); dan bertakwalah kepada Allah, Sesungguhnya Allah Maha mengetahui apa yang kamu kerjakan."(QS. Al-Hasyr: 18)

\section{Deposito Mudharabah}

Menurut UU Nomor 21 Tahun 2008 tentang Perbankan Syariah, deposito adalah investasi dana berdasarkan akad mudharabah atau akad lain yang tidak bertentangan dengan prinsip syariah yang penarikannya hanya dapat dilakukan pada waktu tertentu berdasarkan akad antara nasabah penyimpanana dana dan Bank Syariah atau Unit Usaha Syariah (UUS).

Berdasarkan Fatwa DSN MUI Nomor 3 Tahun 2000 tentang mudharabah menyatakan bahwa deposito yang dibenarkan berdasarkan prinsip syariah adalah deposito dengan menggunakan prinsip mudharabah. Selain giro dan tabungan, produk perbankan syariah lainnya yang termasuk produk penghimpunan dana adalah deposito.

Dalam hal ini Bank Syariah bertindak sebagai mudharib (pengelola dana), sedangkan nasabah bertindak sebagai shahibul maal (pemilik dana). Dalam kapasitasnya sebagai mudharib, Bank Syariah dapat melakukan berbagai macam usaha yang tidak bertentangan dengan prinsip Syariah serta dapat mengembangkannya,

termasuk 
melakukan akad mudharabah dengan pihak ketiga (Ascarya, 2008: 23).

\section{Jenis Deposito Mudharabah}

Terdapat 2 jenis mudharabah, yaitu mudharabah muthlaqah dan muqayyadah. Mudharabah yang digunakan dalam produk deposito bank syariah adalah mudharabah muthlaqah, dimana nasabah memberikan hak sepenuhnya kepada bank untuk menggunakan dananya dan diinvestasikan dalam sektor manapun. Jenis investasi mudharabah muthlaqah dalam aplikasi perbankan syariah dapat ditawarkan dalam produk tabungan dan deposito biasa.

\section{Risiko dalam Pandangan Islam}

Konsep ketidakpastian dalam ekonomi Islam menjadi salah satu pilar penting dalam proses manajemen risiko Islami. Secara natural, dalam kegiatan usaha, di dunia ini tidak ada seorangpun yang menginginkan usaha atau investasinya mengalami kerugian.Bahkan dalam tingkat makro, sebuah Negara juga mengharapkan neraca perdagangannya yang positif. Kaidah syariah tentang imbal hasil dan risiko adalah Al ghunmu bil ghurmi, yang berarti risiko akan selalu menyertai setiap ekspektasi return atau imbal hasil.

\section{Manajemen Risiko}

Menurut PBI No.5/8/PBI/2003 tentang Penerapan Manajemen Risiko Bank Indonesia, bank wajib menerapkan manajemen risiko secara efektif. Penerapan manajemen risiko mencakup:
1) Pengawasan aktif dewan komisaris dan direksi

2) Kecukupan kebijakan, prosedur, dan penetapan limit

3) Kecukupan proses identifikasi, pengukuran, pemantauan, dan pengendalian risiko, serta sistem informasi manajemen risiko

4) Sistem pengendalian yang menyeluruh Imbal Hasil dalam Investasi

Imbal hasil (return) dapat didefinisikan sebagai tingkat keuntungan yang diperoleh atau diharapkan dari suatu investasi selama satu periode waktu, yang akan diperoleh di masa mendatang (Prabowo, 2009).

\section{RAROC (Risk Adjusted Return on Capital)}

RAROC merupakan suatu ukuran profitabilitas yang telah disesuaikan dengan besarnya risiko bahwa pengelolaan memungkinkan untuk alokasi modal, menghubungkan biaya modal dan menyangkut pada risiko kredit (credit risk), risiko pasar (market risk), dan risiko operasional (operational risk) terhadap berbagai macam transaksi, klien dan jalur usaha (Prabowo, 2009).

RAROC model merupakan yang popular digunakan untuk mengevaluasi pendapatan dan risiko kredit berdasarkan harga pasar.Dalam RAROC model indikator penilaiannya diketahui dengan menilai Risk Adjusted Returnnya terhadap loan risk atau capital risk sebagaimana formula berikut. 


$$
\begin{gathered}
\text { RAROC }=\frac{\text { Risk adjudted return }}{\text { Loan (assets)Risk or Capital at Risk }}= \\
\frac{\text { TR-TC-EL }}{\text { WL-EL }}
\end{gathered}
$$

Dimana :

- TR : Total revenue

- TC : Total cost

- $\quad$ EL : Expected loss (\%)

- WL : Worst case loss

\section{Hipotesis dan Model Analisis}

\section{Hipotesis}

Menurut Anshori dan Iswati (2009:45), hipotesis adalah pernyataan hubungan antara variabel dengan variabel, yang bersifat dugaan, atau yang masih lemah. Berdasarkan pada teori dan hasil penelitian sebelumnya, maka hipotesis dari penelitian ini adalah:

$\mathrm{H}_{1}$ : Terdapat perbedaan risiko investasi deposito mudharabah yang signifikan pada Bank Umum Syariah di Indonesia.

$\mathrm{H}_{2}$ : Terdapat perbedaan imbal hasil investasi deposito mudharabah pada Bank Umum Syariah di Indonesia.

\section{METODOLOGI PENELITIAN}

\section{Pendekatan Penelitian}

Penelitian ini menggunakan pendekatan kuantitatif deskriptif dengan jenis studi korelasional.Pemilihan kuantitatif dimaksudkan untuk meringkas dan menghubungkan data (Sugiyono, 2014) berikut berusaha mencari tahu apakah sebuah variabel mampu menyebabkan variabel yang lain (Arikunto, 2016).Sementara deskriptif adalah metode penelitian yang ditujukan untuk menggambarkan fenomena-fenomena yang ada, yang berlangsung pada saat ini atau saat yang lampau.

\section{Identifikasi Variabel}

Variabel dalam penelitian kuantitatif merupakan segala sesuatu yang berbentuk apa saja yang ditetapkan oleh peneliti untuk dipelajari sehingga diperoleh informasi tentang hal tersebut, kemudian ditarik kesimpulan (Sugiyono, 2012). Variabel yang digunakan dalam penelitian dapat diklasifikasikan menjadi variabel risiko dan imbal hasil dalam investasi deposito mudharabah.

\section{Definisi Operasional}

Berikut dijabarkan definisi operasional variabel sebagai pijakan atas variabel-variabel yang digunakan untuk kemudian diuji dalam bab pembahasan selanjutnya:

1. Konsep : Risiko

Definisi : Merupakan besarnya penyimpangan

Operasional antara tingkat pengembalian yang diharapkan dengan pengembalian yang sebenarnya.

Proksi $\sqrt{\frac{\sum_{i=1}^{n}[X i-E(X i)]^{2}}{n-1}}$

2. Konsep : Imbal hasil (return)

Definisi : Berkaitan dengan bagaimana imbal Operasional hasil dari investasi yang merupakan tujuan dari kegiatan investasi.

Proksi $: \frac{P t-(P t-1)}{P t}$

Jenis dan Sumber Data

Sumber data yang digunakan dalam penelitian ini adalah data sekunder, yaitu sumber data penelitian yang diperoleh peneliti secara tidak langsung tetapi melalui media 
perantara.Pengumpulan data dalam penelitian ini dilakukan secara observasi non-participant dengan menggunakan teknik dokumentasi. Penelitian dokumentasi atau studi literatur dilakukan untuk mencari sumber-sumber tertulis dari data kuantitatif perusahaan Bank Umum Syariah di Indonesia yang listing di indeks Bursa Efek Indonesia tahun 2015-2017. Data yang digunakan dalam laporan kevangan terdiri dari risiko dan imbal hasil dengan investasi deposito mudharabah.

\section{Populasi dan Sampel Penelitian}

Sesuai dengan permasalahan penelitian, maka penelitian ini dibatasi dengan menganalisis data sekunder kuantitatif dengan menggunakan populasi yang bersifat makro dan mudah didapat. Populasi penelitian bersifat nonparticipant, dimana penelitian hanya perlu mencatat dan mengkopi data financial report dari sistus resmi www.idx.co.id terkait risiko dan imbal hasil dengan investasi deposito mudharabah pada perusahaan Bank Umum Syariah di Indonesia yang listing di indeks Bursa Efek Indonesia tahun 2015-2017.

Sementara itu, sampel yang digunakan dalam penelitian ini diambil berdasarkan data yang dapat mewakili populasi secara keseluruhan (representatif). Sampel yang digunakan penelitian ini berupa data tahunan dengan penetuan secara purposive sampling dengan kriteria-kriteria berikut:

1. Setiap perusahaan Bank Umum Syariah yang listing di indeks Bursa Efek
Indonesia yang dijadikan sampel penelitian harus menerbitkan laporan tahunan secara konsisten selama periode pengamatan

2. Perusahaan Bank Umum Syariah yang listing di indeks Bursa Efek Indonesia yang terdaftar secara berturut-turut melaporkan investasi deposito mudharabah berdasar risiko dan imbalan hasil dalam laporan keuangannya selama periode 20152017.

3. Perusahaan Bank Umum Syariah yang listing di indeks Bursa Efek Indonesia yang terdaftar secara berturut-turut tidak delisting (keluar) selama 5 tahun berturut-turut selama periode pengamatan dari tahun 2015-2017.

\section{Teknik Analisa Data}

\section{Analisis Statistik Dekriptif}

Statistik deskriptif dilihat dari nilai rata-rata (mean, standar devisiasi, varian, maksimum, minimum, sum, range, kurtosis, dan skwness (kemenangan distribusi)(Ghozali, 2015). Alat yang digunakan untuk menganalisis dan menguji data adalah SPSS. Statistik deskriptif dapat dianalisis dengan prosedur sebagai berikut:

1. Menganalisa perkembangan setiap rasio keuangan dan menjelaskan satu persatu perubahannya dalam setiap perusahaan sampel.

2. Menentukan tingkat rata-rata (mean) dari risiko dan imbal hasil ditinjau dari investasi deposito mudharabah pada 
Bank Umum Syariah di Indonesia yang terdaftar di Bursa Efek Indonesia.

3. Menentukan perbandingan tingkat rata-rata (naik/turun atau membaik/memburuk) risiko dan imbal hasil pada investasi deposito mudharabah pada Bank Umum Syariah di Indonesia.

\section{Uji Normalitas}

Pengujian normalitas dalam penelitian ini menggunakan analisis grafik dan uji One-Sample KolmogorovSmirnov.Untuk melihat normalitas suatu model regresi dapat dideteksi dengan melihat penyebaran data (titik) pada sumbu diagonal dari grafik atau dengan melihat histogram dari residualnya. Adapun dasar pengambilan keputusannya adalah (Ghozali, 2015):

1. Jika data menyebar di sekitar garis diagonal dan mengikuti arah garis diagonal atau grafik histogramnya menunjukkan pola distribusi normal, maka model regresi memenuhi asumsi normalitas.

2. Jika data menyebar jauh dari diagonal dan/atau tidak mengikuti arah garis diagonal atau grafik histogramnya tidak menunjukkan pola distribusi normal, maka model regresi tidak memenuhi asumsi normalitas.

Sedangkan, dasar pengambilan keputusan pada uji One-Sample Kolmogorov-Smirnov adalah residual berdistribusi normal apabila nilai signifikansinya lebih dari 0,05 (Santoso, 2015). Uji normalitas lain menggunakan uji statistik non parametrik KolmogorovSmirnov (K-S). Pedoman pengambilan keputusan tentang data tersebut mendekati atau merupakan distribusi normal berdasarkan Uji K-S dapat dilihat dari (Ghozali, 2015):

1. Jika nilai Sig. atau signifikan normal atau probabilitas < 0,05 maka data tidak berdistribusi normal.

2. Jika nilai Sig. atau signifikan normal atau probabilitas $>0,05$ maka data berdistribusi normal.

\section{Uji Beda}

Variabel independen kuantitatif dalam penelitian ini memiliki dua kategori. Oleh sebab itu, dilakukan pengujian dengan metode uji beda rata-rata untuk dua sampel berpasangan (paired sample t-test). Model uji beda ini digunakan untuk menganalisis perbandingan dua variabel. Uji beda digunakan untuk mengevaluasi perlakuan (treatment) tertentu pada satu sampel yang sama pada dua periode pengamatan yang berbeda. Paired sample t-test digunakan apabila data berdistribusi normal (Ghozali, 2015). Menurut Santoso (2015), paired sample ttest merupakan salah satu metode pengujian yang digunakan untuk mengkaji keefektifan perlakuan, ditandai adanya perbedaan rata-rata sebelum dan rata-rata sesudah diberikan perlakuan. Dasar pengambilan keputusan untuk menerima atau menolak Ho pada uji ini adalah sebagai berikut: 
a. Jika † hitung $>$ † tabel dan probabilitas (Asymp.Sig) < 0,05; maka Ho ditolak dan Ha diterima.

b. Jika † hitung < † tabel dan probabilitas (Asymp.Sig) > 0,05; maka Ho diterima dan Ha ditolak.

Prosedur uji paired sample t-test (Siregar, 2014):

1. Menentukan hipotesis; yaitu sebagai berikut:

a. Hol: Tidak terdapat perbedaan antara risiko dan imbal hasil dengan investasi deposito mudharabah pada Bank Umum Syariah di Indonesia.

b. Ha $\mathrm{Ha}_{1}$ : Terdapat perbedaan antara risiko dan imbal hasil dengan investasi deposito mudharabah pada Bank Umum Syariah di Indonesia.

c. Ho2: Tidak terdapat perbedaan antara risiko dan imbal hasil dengan investasi deposito mudharabah pada Bank Umum Syariah di Indonesia.

d. $\mathrm{Ha}_{2}:$ Terdapat perbedaan antara risiko dan imbal hasil dengan investasi deposito mudharabah pada Bank Umum Syariah di Indonesia.

2. Menentukan level of significant sebesar $5 \%$ atau 0,05

3. Menentukan kriteria pengujian:

a. Ho ditolak jika nilai probabilitas < 0,05, berarti terdapat perbandingan antara risiko dan imbal hasil dengan investasi deposito mudharabah pada Bank Umum Syariah di Indonesia.

b. Ho diterima jika nilai probabilitas > 0,05, berarti tidak terdapat perbandingan antara risiko dan imbal hasil dengan investasi deposito mudharabah pada Bank Umum Syariah di Indonesia.

4. Penarikan kesimpulan berdasarkan pengujian hipotesis.

\section{Uji Hipotesis}

Pengujian hipotesis dilakukan dengan menggunakan software SPSS.Tingkat signifikansi yang digunakan adalah 5\%.Untuk mengetahui perbedaan antara risiko dan imbal hasil dengan investasi deposito mudharabah pada Bank Umum Syariah di Indonesia digunakan uji crosstabs.Pengujian hipotesis dilakukan dengan menggunakan uji pearson chi square. Hipotesis pertama akan diterima jika signifikansi <0,05 (Kadir, 2015). Pengujian hipotesis selanjutnya dilakukan dengan membandingkan meanrisiko dan imbal hasil dengan investasi deposito mudharabah pada Bank Umum Syariah di Indonesia yang diuji dan uji beda T-test sehingga dapat terlihat perbedaan antara kedua variabel.

\section{PEMBAHASAN}

\section{Analisis Risk and Return Berdasarkan}

RAROC

Pendekatan RAROC dalam penelitian ini dimaksudkan untuk mengetahuiseberapa besar risiko ditanggung oleh bank dari pembiayaan 
yang sudah mereka salurkan kepada nasabah pembiayaan, hal ini penting bagi pihak bank untuk mengetahui apakah dana yang mereka salurkan menghasilkan laba atau bahkan menimbulkan kerugian yang nantinya jika terjadi kerugian akan memangkas modal bank.

Nilai RAROC menunjukkan bahwa jika semakin besar Risk Adjusted Return (RAR), maka semakin meningkat pula bobot dari RAROC, artinya ini berbanding lurus.Sedangkan apabila semakin besar Risk Adjusted Capital (RC) maka semakin menurun bobot RAROC, begitupun sebaliknya, artinya ini berbanding terbalik.Berikut perolehan data RAROC yang sudah diolah.

Tabel 2.

Hasil Pengukuran RAROC BUS

(dalam milyar rupiah)

\begin{tabular}{|l|c|c|c|c|c|c|}
\hline Keterangan & $\mathbf{2 0 1 2}$ & $\mathbf{2 0 1 3}$ & $\mathbf{2 0 1 4}$ & $\mathbf{2 0 1 5}$ & $\mathbf{2 0 1 6}$ & $\mathbf{2 0 1 7}$ \\
\hline $\begin{array}{l}\text { EL } \\
\text { (Expected } \\
\text { Loss) }\end{array}$ & 1,734 & 2,027 & 3,108 & 5,020 & 6,940 & 7,895 \\
\hline $\begin{array}{l}\text { Net Profit } \\
\text { (TR-TC) }\end{array}$ & 1,022 & 1,647 & 2,292 & 1,345 & 1,389 & 1,683 \\
\hline $\begin{array}{l}\text { WL (Worst } \\
\text { Case Loss) }\end{array}$ & 2,752 & 3,924 & 5,500 & 6,203 & 6,630 & 7264 \\
\hline $\begin{array}{l}\text { RAR (NP- } \\
\text { EL)* }\end{array}$ & -713 & -380 & -816 & - & - & - \\
\hline $\begin{array}{l}\text { RC (WL-EL)* } \\
\text { RAROC } \\
\text { (RAR/RC) }\end{array}$ & 1,017 & 1,896 & 2,392 & 1,183 & -311 & -631 \\
\hline
\end{tabular}

Sumber: Statistik Perbankan Syariah, data diolah dengan Ms.Excel

Berikut analisis terkait hasil perhitungan RAROC pada BUS: a. RAR (Risk Adjusted Return) menunjukkan adanya kesalahan strategi yang digunakan untuk mempercepat pembayaran utang atau penagihan dari debitur. Nilai RAR yang diperoleh selama periode 20122017 sebesar $-713,-380,-3.674,-5.552$ dan -6.212 milyar rupiah. Hasil RAR secara keseluruhan bernilai negatif dan mengalami penurunan pada tahun 2012 ke tahun 2013, kemudian terus mengalami kenaikan dari tahun 2013 hingga tahun 2016. Kenaikan paling signifikan terjadi pada tahun 2015. Hal ini berarti terdapat risiko atau kerugian dimana total keuntungan yang ada lebih kecil daripada expected loss (rata-rata kerugian). Ini juga mengindikasikan adanya kegagalan manajemen dalam mengelola risiko pembayaran yang ada di BUS. Nilai RAR terbesar terjadi pada tahun 2017 sebesar -6.212 milyar rupiah dan terkecil pada tahun 2013 sebesar -380 milyar rupiah.

b. RC (Risk Capital) menunjukkan modal yang diperlukan untuk menutupi kebutuhan apabila menghadapi suatu masalah karena risiko menjadi kenyataan. RC (Risk Capital) ini dipertimbangkan terhadap suatu yang lebih buruk daripada pembayaran rata-rata kerugian (expected loss). Nilai RC yang diperoleh dari hasil pengukuran dalam milyaran rupiah adalah 1017, 1.896, 2.392, 1183, -311 dan -631 dalam milyaran rupiah selama 
6 tahun. Selama kurun waktu 2012-2017 nilai RC (Risk Capital) terus menerus menunjukkan angka positif. Ketika nilai RC (Risk Capital) positif hal tersebut menunjukkan bahwa BUS memiliki cadangan modal yang dapat menutupi kerugian bila suatu waktu risiko menjadi kenyataan. Sedangkan nilia negative pada RC menggambarkan adanya penaksiran atau estimasi kerugian alokasi modal bank syariah terhadap risiko kredit atau pembiayaan. Hasil analisis RC yang bernilai negative menunjukkan bahwa expected loss mengaklami peningkatan selama periode tersebut. Artinya modal BUS yang sudah disesuaikan dengan besarnya risiko mengalami potensi peningkatan risiko. Angka negatif RC terjadi pada tahun 2016 dan 2017 sebesar -311 dan -631 dala milyar rupiah.

c. Hasil pengukuran RAROC digunakan sebagai alat analisis dalam menilai bobot bersih dari keuntungan (net profit) yang diperoleh dari kegiatan usaha yang dilakukan oleh bank syariah. Bobot bersih dari keuntungan yang dimaksud adalah nilai pendapatan yang telah disesuaikan apabila kerugian yang telah dialokasikan benar-benar terjadi. Sehingga dalam hal ini dapat diketahui net profit yang sebenarnya diperoleh oleh bank syariah. Adapun hasil RAROC selama tahun 2012-2017 pada penelitian ini adalah sebesar -0,70; -
0,20; -0,34; -3,10; 17.87; dan 9.85 secara berturut-turut. Nilai RAROC terbesar terjadi pada tahun 2016 yaitu 17,87 dan yang terendah sebesar $-3,10$ yang terdapat pada tahun 2015. RAROC yang bernilai negatif mengindikasikan adanya potensi kerugian karena nilai RAR yang negatif, dimana akan berdampak buruk pada BUS, apabila kerugian terealisasi maka kerugian tersebut akan menggerus modal dari BUS untuk menutupi kerugian tersebut. Sedangkan RAROC yang bernilai positif seharusnya menunjukkan adanya perbaikan kinerja bank sehingga bobot bersih imbal hasil (return) yang disesuaikan dengan risiko mengalami peningkatan. Hal itu berlaku jika hasil RAR dan RC bernilai positif juga. Dalam penelitian ini RAR dan RC keduanya bernilai negatif, ini mengindikasikan adanya kerugian karna nilai expected loss lebih be daripada keuntungan yang didapat dan modal tidak mampu menutupi kerugian tersebut.

\section{Perbedaan antara Risiko dengan Investasi} Deposito Mudharabah Pada Bank Umum Syariah

Hasil pengujian hipotesis menyatakan bahwa terdapat perbedaan yang signifikan antara Risiko dengan investasi deposito mudharabah pada Bank Umum Syariah. Terdukunganya hipotesis ini didasarkan atas nilai rata-rata Risiko pada investasi deposito mudharabah pada Bank Umum Syariah sebesar -0,06448, dan nilai signifikansi 
sebesar 0,038 ( $p<0,05)$. Hal tersebut menunjukkan bahwa kedua varians adalah tidak sama dan berbeda.

Perbedaan antara Imbal Hasil dengan Investasi Deposito Mudharabah Pada Bank Umum Syariah

Hasil pengujian hipotesis menyatakan bahwa terdapat perbedaan yang signifikan antara Return dengan investasi deposito mudharabah pada Bank Umum Syariah. Terdukunganya hipotesis ini didasarkan atas nilai rata-rata Return pada investasi deposito mudharabah pada Bank Umum Syariah sebesar 0,10163, dan nilai signifikansi sebesar 0,038 ( $p<0,05)$. Hal tersebut menunjukkan bahwa kedua varians adalah tidak sama dan berbeda.

\section{SIMPULAN}

Berikut adalah kesimpulan dari hasil analisis dan pembahasan:

1. Terdapat perbedaan yang signifikan antara Risiko dengan investasi deposito mudharabah pada Bank Umum Syariah. Terdukunganya hipotesis ini didasarkan atas nilai rata-rata Risiko pada investasi deposito mudharabah pada Bank Umum Syariah sebesar 0,06448, dan nilai signifikansi sebesar $0,038$ ( $p<0,05)$. Hal tersebut menunjukkan bahwa kedua varians adalah tidak sama dan berbeda.

2. Terdapat perbedaan yang signifikan antara Return dengan investasi deposito mudharabah pada Bank Umum Syariah. Terdukunganya hipotesis ini didasarkan atas nilai rata- rata Return pada investasi deposito mudharabah pada Bank Umum Syariah sebesar 0,10163, dan nilai signifikansi sebesar 0,038 ( $p<0,05)$. Hal tersebut menunjukkan bahwa kedua varians adalah tidak sama dan berbeda.

3. Analisis Risk Adjusted Return on Capital (RAROC) menggambarkan tingkat pendapatan yang diperoleh bank syariah yang telah disesuaikan dengan risiko yang akan terjadi, hal tersebut menunjukkan pendapatan yang didapat Bank Umum Syariah belum dapat menutupi kemungkinan potensi kerugian yang akan terjadi. Hasil RAROC menunjukkan angka berikut tiap tahunnya $-0,70 ;-0,20 ;-0,34,-3,10$; 17,87 dan 9,85 . Nilai RAR menunjukkan angka negatif secara keseluruhan yang menandakan risiko tersebut berpotensi menggerus modal Bank Umum Syariah. Dapat dikatakan bahwa potensi risiko yang terjadi di BUS lebih tinggi daripada imbal hasil yang didapat. Artinya bahwa perbedaan antara risiko dan imbal hasil melalui metode ini sangat terlihat.

\section{DAFTAR PUSTAKA}

Al Qur'an dan Terjemahannya. 2014. Jakarta: Kementrian Agama RI.

Anshori, Muslich Dan Sri Iswati. 2009. Buku Ajar Metodologi Penelitian Kualitatif. Surabaya: Pusat Penerbitan dan Percetakan Unair (AUP). 
Ascaraya.2008. Akad dan Produk Bank Syariah. Jakarta: PT Raja Grafindo Persada.

Aziz, Abdul. 2010. Manajemen Investasi Syariah. Bandung: Alfabeta.

Basyaib Fachmi. 2007. Manajemen Risiko. Jakarta: PT Gramedia.

Fahmi, Irham. 2013. Rahasia Saham dan Obligasi. Bandung: Alfabeta. 2015. Manajemen Investasi: Teori dan Soal Jawab, Edisi 2. Jakarta Selatan: Salemba Empat.

Halim, Abdul. 2009. Analisis Kelayakan Investasi Bisnis Kajian dari Aspek Kevangan, Edisi pertama. Yogyakarta: Graha IImu

Hasibuan, Melayu S.P. 2001. Dasar-Dasar Perbankan. Jakarta: PT Bumi Aksara.

Hidayat, Taufik. 2011. Buku Pintar Investasi Syariah. Jakarta : Media Kita.

Huda, Nurul. 2008. Investasi Pasar Modal Syariah, Edisi Revisi. Jakarta: Kencana.

Hull, J.. 2007. Risk Management And Financial Institutions. $2^{\text {nd }}$ ed. Boston: Pearson.

Ismail. 2011. Perbankan Syariah. Jakarta: Kencana.

Idrus, N Ferry. 2011. Manajemen Risiko Perbankan Syariah. Jakarta: PT Raja Grafindo Persada.

Jogiyanto.2000. Teori Portofolio dan Analisis Investasi, Edisi Kelima. Yogyakarta: PT BPFE Yogyakarta.

Jorion, P.H.. 1996. Value at Risk: The New Brenchmark for Measuring
Derivatives Risk, third ed. McGrawHill, New York, NY.

Karim, Adiwarman. 2010. Bank Islam: Analisis Fiqih dan Keuangan, Edisi 4. Jakarta: PT Raja Grafindo Persada.

Kasmir. 2008. Analisis Laporan Kevangan. Jakarta: PT Raja Grafindo Persada.

2008. Bank dan Lembaga Keuangan, Edisi Revisi. Jakarta: PT Raja Grafindo Persada.

2010. Manajemen Perbankan. Jakarta: Rajawali Pers.

Khairunnisa, Anindytia Clara. 2015. Risk Adjusted Return On Capital dan Economic Value Added Studi Empiris pada Industri Perbankan pada Tahun 2008-2013. Volume 2.

Markowitz, H. 1952. Portofolio Selection.Jurnal of Finance 7: pp77-91.

Muhammad. 2005. Manajemen Bank Syariah: Edisi Revisi, Cet. 1 . Yogyakarta: UPP AMP YKPN.

Peraturan Bank Indonesia No.5/8/PBI/2003; diakses pada tanggal 28 Desember 2018 pukul 18.25 wib dari http://www.bi.go.id/

Sudarsono, Heri. 2008. Bank dan Lembaga Keuangan Syariah, Cetakan Ke-2. Yogyakarta: Ekonisia.

Sunariyah. 2004. Pengantar Pengetahuan Pasar Modal: Edisi Kelima. Bandung: CV Alfabeta.

Tambunan. 2007. Menilai Harga Wajar Saham. Jakarta: PT Gramedia Pusaka Utama. 
Tandelilin Eduardus. 2011. Analisis Investasi dan Manajemen Portofolio: Edisi Pertama. Yogyakarta: Ekonisia.

Wiroso.2011. Produk Perbankaan Syariah, Cetakan Ke-2. Jakarta: LPFE Usakti.

Wiku Suryomurti. Konsep dalam Islam, artikel diakses pada tanggal 28 Desember 2018 pukul 18.50 wib dari

http://www.wikusuryomurti.com/ko nsep-dalam-Islam/

Yudho, Prabowo. 2009. Analisis Resiko dan Pengembalian Hasil pada
Perbankan Syariah: Aplikasi Metode VaR dan RAROC pada BSM. Jurnal Ekonomi Islam La_Riba Vol. III. No.1.Yogyakarta: Fakultas IImu Agama Islam UII. 